
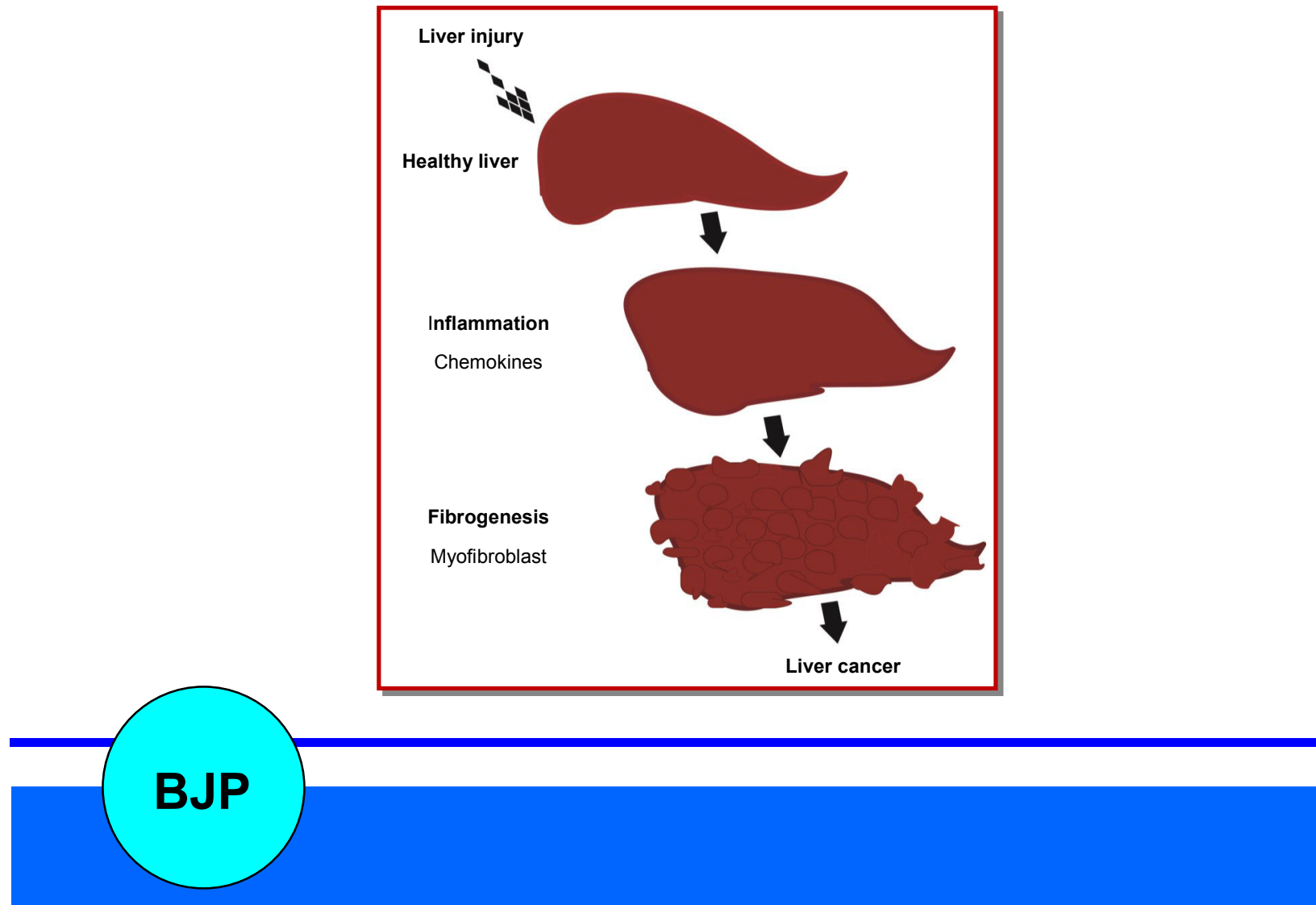

Bangladesh Journal of Pharmacology

Mini Review

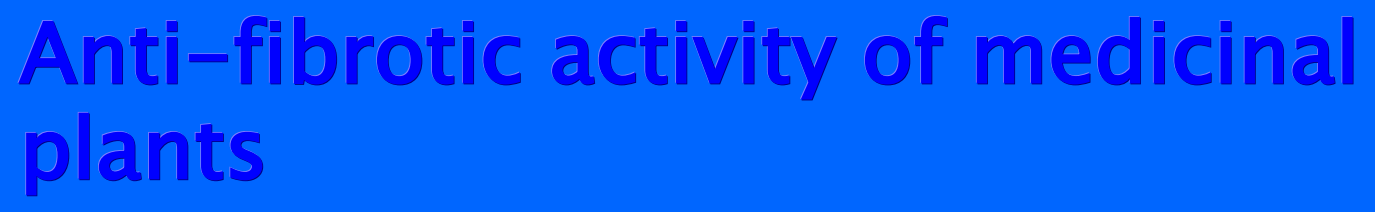


Abstracted/indexed in Academic Search Complete, Asia Journals Online, Bangladesh Journals Online, Biological Abstracts, BIOSIS Previews, CAB Abstracts, Current Abstracts, Directory of Open Access Journals, EMBASE/Excerpta Medica, Global Health, Google Scholar, HINARI (WHO), International Pharmaceutical Abstracts, Open J-gate, Science Citation Index Expanded, SCOPUS and Social Sciences Citation Index;

ISSN: $1991-0088$

\section{Anti-fibrotic activity of medicinal plants}

\section{Usman Akhtar and Mobasher Ahmad}

Department of Pharmacology, University College of Pharmacy, University of the Punjab, Lahore, Pakistan.

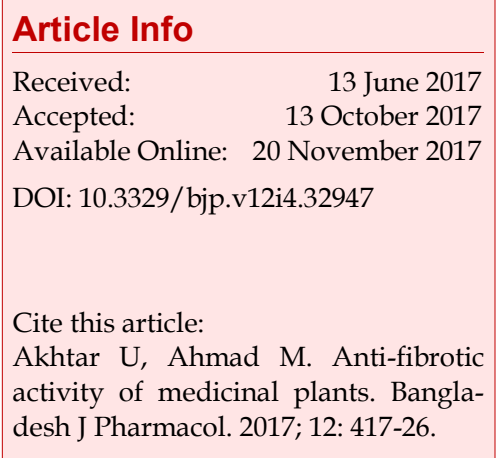

\begin{abstract}
The aim of this review is to report the medicinal plants which have antifibrotic effect characterized in different studies. They are summarized which include name of the plants, part used, liver fibrosis model, fraction of plant used and observations. The medicinal plants play an important role in treatment and prevention of liver fibrosis through different physiological mechanism. The effects of medicinal plant may delay the development of liver fibrosis and have potential to reverse or degrade the accumulation of extra cellular matrix. Four different databases are used and 18 plants are included which have the potential for reversal of liver fibrosis. There are also few more plants but they are not characterized well in literature.
\end{abstract}

\section{Introduction}

Worldwide $80 \%$ of people rely on the use of traditional medicine and these have a characteristic role in human health care system (WHO, 1993). These include a broad range of prehistoric natural health care system like folk practices, Ayurveda, Siddha, Amchi. These were originated from time immemorial and gradually developed based on experiences without any scientific protocols. These traditional medicines were transferred from one generation to another generation by oral or guarded literature.

\section{Liver Fibrosis}

Liver fibrosis is the pathophysiologic process due to chronic liver injury, recognized by the accumulation of extra cellular matrix (Paik et al., 2014). For in vivo studies, carbon tetrachloride $\left(\mathrm{CCl}_{4}\right)$ has been widely used to study liver fibrosis in experimental rodents (Uehara et al., 2014). Fibrosis is a protective response to any type of tissue injury. Fibrosis may be self limiting and homeostatic, or it may be uncontrolled and excessive determined by the different pathways, molecules and systems. Immune cells play a leading role in this fibrotic cascade, with the ability to exert either repair promoting or injury inducing effects (Pellicoro et al., 2014). The important role of normal liver is in maintaining the homeostasis of the body. Liver has regeneration capacity which enables it to withstand against functional parenchymal loss or liver injury. When liver is subjected to a continuous liver injury it loses its regeneration ability. Irrespective of the cause, liver injuries generally result in accumulation of extracellular matrix proteins and causes fibrosis. After continuous injury oxidative stress is produced by several sources can influence liver fibrosis. The cytochrome P4502E1 enzyme mainly found in liver and is one of the potential sources of oxidative stress. This enzyme is induced by ethanol and in alcohol-induced liver diseases. Similarly, the phagocytic NADPH oxidase in the Kupffer cells is another potential source of oxidative stress. Several evidences indicate the pivotal role of oxidative stress in liver fibrosis. Nicotinamide adenine dinucleotide phosphate (NADPH) oxidase, is an enzyme complex that exerts oxidative stress through production of reactive oxygen species (ROS) (Paik et al., 2014). In liver, phagocytic and non-phagocytic forms of NADPH oxidase are functionally expressed. Both are structurally and functionally similar that generate superoxide by reduction of molecular oxygen. Non- 
phagocytic form of NADPH oxidase contains six types of homologous NOX proteins. It is now believed that both forms of NADPH oxidase in hepatic stellate cells mediate liver fibrosis (Paik and Brenner, 2011).

\section{Animal Model of Liver Fibrosis}

Different animals are used in the study of liver fibrosis and cirrhosis. The suitable animal should be considered regarding the purpose of study in accordance with pathogenesis of liver fibrosis. The animals used in the study of liver fibrosis are (in order of frequency) rat, mouse, rabbit, dog, guinea pig, micropig, monkey and baboon. Rodents (rat and mouse) are extensively used to study liver fibrosis because they can easily provide study cell and molecular mediators of liver fibrosis during the progression (Figure 1) and reversal of fibrosis (Constandinou et al., 2005).

The commonly used chemical substances to induce liver fibrosis in animal model are $\mathrm{CCl}_{4}$, thioacetamide (TAA), dimethylnitrosamine (DMN), and diethylnitrosamine (DEN) (Delire et al., 2015). $\mathrm{CCl}_{4}$ is widely used because $\mathrm{CCl}_{4}$ induced model is best with respect to all changes (e.g., histological, biochemical, molecular and cell changes) which leads to the development of liver fibrosis. $\mathrm{CCl}_{4}$ administration can induce the zone III necrosis and apoptosis of hepatocytes which leads to hepatic stellate cell activation and fibrosis. With chronic administration, $\mathrm{CCl}_{4}$ can induce bridging liver fibrosis (4 weeks with twice week dosing) or cirrhosis (8 weeks with twice week dosing).

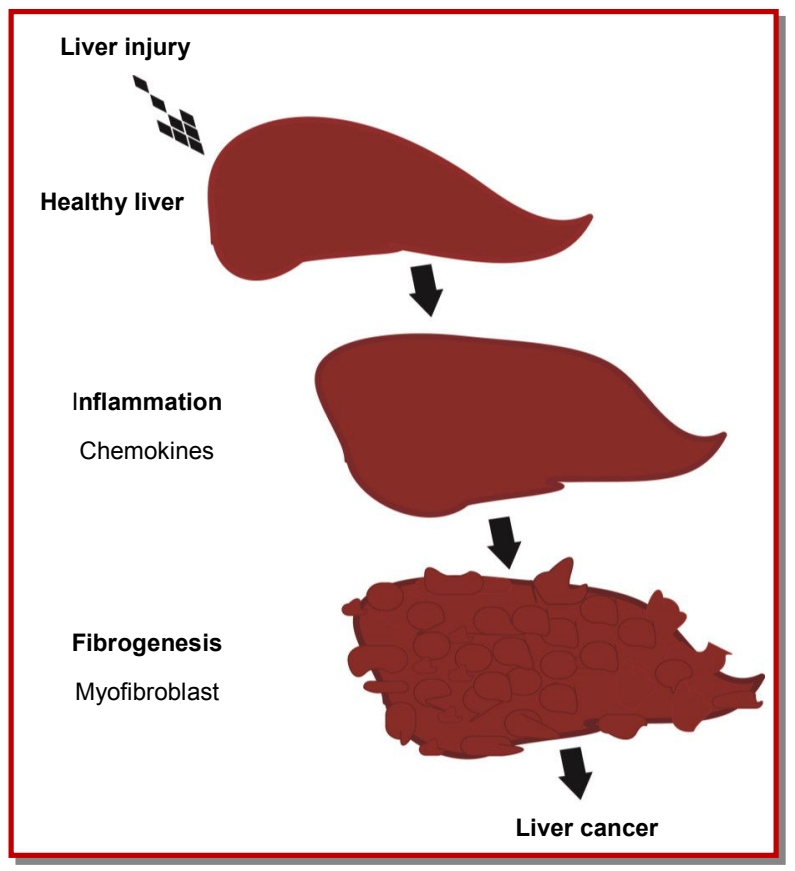

Figure 1: Progression of liver fibrosis which leads to cancer
The other most commonly used method to develop liver fibrosis is bile duct ligation. Bile duct ligation is most commonly used in rat model because there is no gall bladder. In the mouse model, it is considered as a drawback due to leakage or rupture of biliary cyst (Liu et al., 2013). In short, this whole procedure for bile duct ligation requires a midventral laparotomy and separation of the bile duct above the duodenum, usually, this procedure was then followed by double ligation and dissection of the bile duct between the ligatures (Starkel and Leclercq, 2011).

\section{Reversal of Liver Fibrosis}

Liver fibrosis is a constant process in which two pathways co-exist and interact i.e., fibrogenic pathway and fibrolytic pathway. During the liver damage, hepatic stellate cells become activate and proliferate due to activating mediators and antiapoptotic factors respectively. Therefore, activated hepatic stellate cells produce an excessive accumulation of extracellular matrix and its degradation is prevented by increased activity of tissue inhibitors of metalloproteinases (TIMPS) that leads to fibrogenic condition. After removal of the causative agents of liver injury, apoptosis of hepatic stellate cells takes place with the decreased in the activity of TIMPs followed by increased activity of tissue matrix metalloproteinases which exert their fibrolytic activity, initiate the process known as remodeling (Bataller and Brenner, 2005; Benyon and Iredale, 2000).

In animal models of liver fibrosis, the reversal of liver fibrosis has been characterized by the removal of the causative agent $\left(\mathrm{CCl}_{4}\right.$ infusion and bile duct ligation) (Abdel-Aziz et al., 1990). Similarly, in humans reversal of liver fibrosis has also been characterized by the removal and treatment of the causative agent, such as alcoholic liver disease, copper and iron overload, viral hepatitis and auto-immune hepatitis (Bataller and Brenner, 2005; Hammel et al., 2001). The most studied condition is of hepatitis C. As hepatitis C is successfully treated with interferon a plus ribavirin, almost half of the patients showed a significant improvement in liver fibrosis (Arthur, 2002; Benyon and Iredale, 2000). However, several fundamental questions are still to be answered about the resolution of liver fibrosis. Several clinical evidences have characterized that fibrosis/cirrhosis not only resolved (histological reversion), but there are evidence that also showed improved clinical condition (Friedman and Bansal, 2006; Mallet et al., 2008). As previously described, reversibility of liver fibrosis is mainly due to decreased TIMPs expression and the activity of increased interstitial collagenases that is helpful in the clearance of activated hepatic stellate cells which is due to apoptosis, senescence or reversion to quiescence (Gonzalez et al., 2009). 
The senescent hepatic myofibroblast may be helpful in the resolution of liver fibrosis. It may decrease or stop proliferation. It also increases the expression of matrix degrading enzymes and decreases the expression of extracellular matrix proteins. It can be easily cleared by the natural killer cells in vitro and in vivo, therefore, contribute to the resolution of liver fibrosis (Krizhanovsky et al., 2008).

Fibrous scar is produced by the myofibroblast which is the activated form of quiescent hepatic stellate cells in the liver fibrosis induced by $\mathrm{CCl}_{4}$ in the rodent model and after the removal of the causative agent $\left(\mathrm{CCl}_{4}\right)$, there is significant regression in clinical and experimental fibrosis with complete clearance of these myofibroblasts. However, some are cleared by apoptosis. It is unknown whether other cells may revert during regression of liver fibrosis to an inactive phenotype and retain a state with more ability to react more rapidly to fibrotic stimuli and strongly participate in liver fibrosis (Kisseleva et al., 2012).

In the present work, the articles of natural plants activity in $\mathrm{CCl}_{4}$-induced liver fibrosis have been reviewed (Table I).

\section{Medicinal Plants having Antifibrotic Activity \\ Rhodiola sachalinensis}

The root of the Rhodiola sachalinensis is used in the traditional treatment in Siberia and Asia. The therapeutic compounds isolated from this plant have anti-diabetic (Cheng et al., 1993), sedative, hypnotic, anti inflammatory, anti-oxidant potential (Choe et al., 2012; Lee et al., 2000) and hepatoprotective effects (Nan et al., 2003b). The root extract has protective effect in the liver injury of rat model induced by continuous administration of $\mathrm{CCl}_{4}$. The extract was administered for 28 days through oral route at doses of 50,100, $200 \mathrm{mg} / \mathrm{kg}$ continuously with $\mathrm{CCl}_{4}$. Comparison of malondialdehyde (MDA) and hydroxyproline in the liver and enzyme activities in the serum of $\mathrm{CCl}_{4}$-treated rat showed a significant increase when compared to rat treated with plant extract. The plant extract significantly inhibits the hepatic stellate cell activation, as observed in the immunohistological findings.

\section{Salvia miltiorrhiza}

Salvia miltiorrhiza is widely used medicinal plant as oral herbs in different countries for the treatment of different diseases (Kim et al., 2010). The root is pharmacologically important to prevent acute liver damage and also reduces the liver fibrosis induced by $\mathrm{CCl}_{4}$ in animal model (Lee et al., 2003; Nan et al., 2001; Qi, 1991). The hot extract of the herb inhibits the liver fibrosis induced by biliary obstruction. After bile duct ligation surgery, the root extract was administered orally for 28 days through oral route at a dose of 100 $\mathrm{mg} / \mathrm{kg}$. The concentration of different enzymes was observed including serum aminotransferases, alkaline phosphatase, total bilirubin, malondialdehyde, hydroxyproline and total cholesterol in serum. Rat receiving plant extract after surgery had a significant low level of the above enzymes when compared to the rat which received only vehicle control. The tissue section studies also showed improved morphological characteristics in rat receiving plant extract. a-Smooth muscle protein expression also showed reduced expression which indicates hepatic stellate cell activation was inhibited during the fibrotic liver progression (Nan et al., 2001).

\section{Aloe vera and Silybum marianum}

Aloe vera is usually found in the deserts. Its leaves are pharmacologically important for the treatment of liver and spleen enlargement and also in eyes disorders (Chandan et al., 2007). Basically, they are important for its anti-inflammatory and anti-oxidative properties (Can et al., 2004; Lim et al., 2003). Likewise, S. marianum is also used to treat biliary and liver diseases because of its strong anti-oxidant potential (Post-White et al., 2007; Vaknin et al., 2008). The mixture of both plants against the acute liver injury and chronic liver fibrosis model in mice after administration of $\mathrm{CCl}_{4}$ was studied. In acute liver injury, $\mathrm{CCl}_{4}$ was intraperitoneal injected $(50 \mu \mathrm{L} /$ $\mathrm{kg}$ ) alone and with 85,170 and $340 \mathrm{mg} / \mathrm{kg}$ dose of mixture of plant was administered orally after 2 and 6 hours after injection. Liver toxicity was observed after 24 hours of injection. Chronic liver injury mice model was first prepared by intraperitoneal injection of $\mathrm{CCl}_{4}$ for 8 weeks $(0.5 \mathrm{~mL} / \mathrm{kg}$, twice per week) and mice were treated with mixture at dose of $85,170,340 \mathrm{mg} / \mathrm{kg}$ once a day orally. In both studies acute and chronic, aminotransferase concentration and lipid peroxidation were significantly increased and the liver glutathione content was decreased. Administration of plant in acute and chronic injury decrease aminotransferase concentration and lipid peroxidation and normalize liver glutathione level. In acute phase of injury, the plant mixture significantly reduces the expression of tumor necrosis factor- $a$ and also effects nitric oxide synthase and cyclooxygenase-2. In chronic phase injury, tissue inhibitor of metalloprotease-1 mRNA was downregulated by treatment (Kim et al., 2009b).

\section{Artemisia iwayomogi}

Artemisia iwayomogi is a perennial herb from Korea having traditional medicinal importance in the treatment of different disorders. Hot water extract and methanol extract of $A$. iwaymogi significantly improve the microenvironment of liver and also reduces the progression of liver fibrosis induced by $\mathrm{CCl}_{4}$. $\mathrm{CCl}_{4}$ was orally administered twice a week at a dose of $1 \mathrm{~mL} / \mathrm{kg}$ for 4 weeks and they also received the plant extract orally at a dose of $2 \mathrm{~g} / \mathrm{kg}$ for 4 weeks. After 4 weeks, the liver hydroxyproline concentration was signifi- 
Table I

Plants used in treatment of liver fibrosis

\begin{tabular}{|c|c|c|c|c|c|}
\hline Name of the plant & Plant parts & $\begin{array}{l}\text { Liver fibrosis } \\
\text { inducing } \\
\text { agents }\end{array}$ & $\begin{array}{l}\text { Animal } \\
\text { model }\end{array}$ & $\begin{array}{l}\text { Extracts } \\
\text { studied }\end{array}$ & $\begin{array}{l}\text { Biochemical and histopathological } \\
\text { parameters studied }\end{array}$ \\
\hline $\begin{array}{l}\text { Rhodiola sacha- } \\
\text { linensis (Nan et } \\
\text { al., 2003a) }\end{array}$ & Root & $\begin{array}{l}\text { Carbon tetra- } \\
\text { chloride }\end{array}$ & Rat & Aqueous & $\begin{array}{l}\text { Hydroxyproline, malondialdehyde, serum } \\
\text { enzyme activities, masson's trichome method, } \\
\text { smooth muscle cell a-actin }\end{array}$ \\
\hline $\begin{array}{l}\text { Salvia miltiorrhiza } \\
\text { (Nan et al., 2001) }\end{array}$ & $\begin{array}{l}\text { Whole } \\
\text { herb }\end{array}$ & $\begin{array}{l}\text { Bile duct liga- } \\
\text { tion }\end{array}$ & Rat & $\begin{array}{l}\text { Hot- } \\
\text { water } \\
\text { extract }\end{array}$ & $\begin{array}{l}\text { Aminotransferases, alkaline phosphatase, total } \\
\text { bilirubin, total cholesterol in serum, hydroxy- } \\
\text { proline, malondialdehyde, protein expression } \\
\text { of a-smooth muscle cell-like actin }\end{array}$ \\
\hline $\begin{array}{l}\text { Aloe vera } \\
\text { and Silybum mari- } \\
\text { anum (Kim et al., } \\
\text { 2009a) }\end{array}$ & Leaf & $\begin{array}{l}\text { Carbon tetra- } \\
\text { chloride }\end{array}$ & Mouse & & $\begin{array}{l}\text { Tumor necrosis factor-a, inducible nitric oxide } \\
\text { synthase, cyclooxygenase-2, mRNA expres- } \\
\text { sions, tissue inhibitor of metalloprotease- } 1\end{array}$ \\
\hline $\begin{array}{l}\text { Artemisia iwayo- } \\
\text { mogi (Park et al., } \\
\text { 2000) }\end{array}$ & Aerial part & $\begin{array}{l}\text { Carbon tetra- } \\
\text { chloride }\end{array}$ & Rat & $\begin{array}{l}\text { Hot- } \\
\text { water } \\
\text { extract }\end{array}$ & $\begin{array}{l}\text { Hydroxyproline content, protein expression of } \\
\text { alpha smooth muscle cell actin, liver } \\
\text { malondialdehyde, serum cholesterol }\end{array}$ \\
\hline $\begin{array}{l}\text { Stephania tetrandra } \\
\text { (Park et al., 2000b) }\end{array}$ & $\begin{array}{l}\text { Chinese } \\
\text { medicinal } \\
\text { herb }\end{array}$ & $\begin{array}{l}\text { Bile duct liga- } \\
\text { tion and scis- } \\
\text { sion }\end{array}$ & Rat & $\begin{array}{l}\text { Isolated } \\
\text { alkaloid }\end{array}$ & $\begin{array}{l}\text { Serum aminotransferases, alkaline phospha- } \\
\text { tase, cultured rat hepatic stellate cells }\end{array}$ \\
\hline $\begin{array}{l}\text { Gynostemma pen- } \\
\text { taphyllum(Chen et } \\
\text { al., 2000) }\end{array}$ & $\begin{array}{l}\text { Whole } \\
\text { plant }\end{array}$ & $\begin{array}{l}\text { Carbon tetra- } \\
\text { chloride }\end{array}$ & Rat & $\begin{array}{l}\text { Saponin } \\
\text { extract }\end{array}$ & $\begin{array}{l}\text { Serum aminotransferases, pathologic observa- } \\
\text { tion }\end{array}$ \\
\hline $\begin{array}{l}\text { Hibiscus sabdariffa } \\
\text { (Liu et al., 2006a) }\end{array}$ & $\begin{array}{l}\text { Dried } \\
\text { flower }\end{array}$ & $\begin{array}{l}\text { Carbon tetra- } \\
\text { chloride }\end{array}$ & Rat & & $\begin{array}{l}\text { Serum aminotransferases, glutathione, hepatic } \\
\text { lipid peroxidation, immunofloresence staining }\end{array}$ \\
\hline $\begin{array}{l}\text { Scutellaria bai- } \\
\text { calensis Georgi } \\
\text { (Nan et al., 2002) }\end{array}$ & $\begin{array}{l}\text { Chinese } \\
\text { medicinal } \\
\text { herb, the } \\
\text { root }\end{array}$ & $\begin{array}{l}\text { Bile duct liga- } \\
\text { tion and scis- } \\
\text { sion (BDL) or } \\
\text { carbon tetra- } \\
\text { chloride }\end{array}$ & Rat & $\begin{array}{l}\text { Metha- } \\
\text { nol ex- } \\
\text { tract }\end{array}$ & $\begin{array}{l}\text { Histological observations, liver hydroxy- } \\
\text { proline, lipid peroxidation based on malondial- } \\
\text { dehyde production, serum enzyme activities, } \\
\text { Masson's trichrome staining, immunostaining } \\
\text { against smooth muscle cell a-actin }\end{array}$ \\
\hline $\begin{array}{l}\text { Piper betel (Young } \\
\text { et al., 2007) }\end{array}$ & Leaf & $\begin{array}{l}\text { Carbon tetra- } \\
\text { chloride }\end{array}$ & Rat & ddH2O & $\begin{array}{l}\text { Pathological histology, glutathione S- } \\
\text { transferase activity assay, superoxide dis- } \\
\text { mutase, catalase activity, Lucigenin-enhanced } \\
\text { chemiluminescence, immunohistochemistry, } \\
\text { matrix metalloproteinase-2 activity assay, } \\
\text { Western blot analysis }\end{array}$ \\
\hline $\begin{array}{l}\text { Foeniculum vulgare } \\
\text { (Özbek et al., } \\
\text { 2004) }\end{array}$ & Seed & $\begin{array}{l}\text { Carbon tetra- } \\
\text { chloride }\end{array}$ & Rat & $\begin{array}{l}\text { Essential } \\
\text { oil }\end{array}$ & $\begin{array}{l}\text { Serum aminotransferases, alkaline phospha- } \\
\text { tase, bilirubin, histopathological findings, body } \\
\text { weight }\end{array}$ \\
\hline $\begin{array}{l}\text { Bidens pilosa } \mathrm{L} \\
\text { (Yuan et al., } \\
\text { 2008a) }\end{array}$ & Dried leaf & $\begin{array}{l}\text { Carbon tetra- } \\
\text { chloride }\end{array}$ & Mouse & $\begin{array}{l}80 \% \\
\text { Ethanol }\end{array}$ & $\begin{array}{l}\text { Serum aminotransferases, hepatic malondialde- } \\
\text { hyde, superoxide dismutase, glutathione pe- } \\
\text { roxidase (GSH-Px) }\end{array}$ \\
\hline $\begin{array}{l}\text { Han-Dan-Gan-Le } \\
\text { (HDGL) (Li et al., } \\
\text { 2003) }\end{array}$ & Herb & $\begin{array}{l}\text { Carbon tetra- } \\
\text { chloride }\end{array}$ & Rat & $\begin{array}{l}\text { Chinese } \\
\text { herb } \\
\text { prepara- } \\
\text { tion }\end{array}$ & $\begin{array}{l}\text { Hyroxyplonine analysis, histopatholog1cal } \\
\text { examination, imminohistochemistry }\end{array}$ \\
\hline $\begin{array}{l}\text { Lygodium flexu- } \\
\text { osum (Wills and } \\
\text { Asha, 2007) }\end{array}$ & $\begin{array}{l}\text { Dried } \\
\text { powder of } \\
\text { the whole } \\
\text { plant }\end{array}$ & $\begin{array}{l}\text { Carbon tetra- } \\
\text { chloride }\end{array}$ & Rat & $\begin{array}{l}\mathrm{n}- \\
\text { Hexane }\end{array}$ & $\begin{array}{l}\text { Western blot analysis of collagen-III, immuno- } \\
\text { histochemical analysis, hepatic markers }\end{array}$ \\
\hline
\end{tabular}


Table I

Plants used in treatment of liver fibrosis (Continued)

\begin{tabular}{|c|c|c|c|c|c|}
\hline Name of the plant & Plant parts & $\begin{array}{l}\text { Liver fibrosis } \\
\text { inducing } \\
\text { agents }\end{array}$ & $\begin{array}{l}\text { Animal } \\
\text { model }\end{array}$ & $\begin{array}{l}\text { Extracts } \\
\text { studied }\end{array}$ & $\begin{array}{l}\text { Biochemical and histopathological } \\
\text { parameters studied }\end{array}$ \\
\hline $\begin{array}{l}\text { Paeonia lactiflora } \\
\text { and Radix Astraga- } \\
\text { li (Sun et al., 2007) }\end{array}$ & Dried root & $\begin{array}{l}\text { Carbon tetra- } \\
\text { chloride }\end{array}$ & Rat & $\begin{array}{l}70 \% \\
\text { Aque- } \\
\text { ous } \\
\text { ethanol, }\end{array}$ & $\begin{array}{l}\text { ALT and AST, hydroxyproline content in liver, } \\
\text { Measurement of serum fibrotic markers and } \\
\text { serum TGF- } \beta 1 \text {, hematoxylin and eosin (HE), } \\
\text { MDA }\end{array}$ \\
\hline $\begin{array}{l}\text { Zizyphusspina- } \\
\text { christi (Amin and } \\
\text { Mahmoud- } \\
\text { Ghoneim, 2009a) }\end{array}$ & $\begin{array}{l}\text { Whole } \\
\text { plant }\end{array}$ & $\begin{array}{l}\text { Carbon tetra- } \\
\text { chloride }\end{array}$ & Rat & $\begin{array}{l}50 \% \\
\text { Ethanol } \\
\text { and } \\
50 \% \\
\text { water }\end{array}$ & $\begin{array}{l}\text { Type I collage immuno-stained liver slides, } \\
\text { malondialdehyde (MDA), catalase (CAT) activi- } \\
\text { ty, superoxide dismutase (SOD) enzyme activity, } \\
\text { Protein carbonyl (P. carbonyl) contents, total } \\
\text { protein contents, Myeloperoxidase (MPO) activi- } \\
\text { ty }\end{array}$ \\
\hline $\begin{array}{l}\text { Green tea } \\
\text { (Safer et al., 2015) }\end{array}$ & & $\begin{array}{l}\text { Carbon tetra- } \\
\text { chloride, etha- } \\
\text { nol }\end{array}$ & Rat & $\begin{array}{l}\text { Green } \\
\text { tea } \\
\text { extract }\end{array}$ & $\begin{array}{l}\text { Histopathological study, alanine aminotransfer- } \\
\text { ase; aspartate aminotransferase }\end{array}$ \\
\hline $\begin{array}{l}\text { Ocimum gratissi- } \\
\text { mum (Chen et al., } \\
\text { 2015) }\end{array}$ & Herb & $\begin{array}{l}\text { Carbon tetra- } \\
\text { chloride }\end{array}$ & Rat & $\begin{array}{l}\text { Poly- } \\
\text { phenol } \\
\text { extract }\end{array}$ & $\begin{array}{l}\text { Serum alanine aminotransferase and aspartate } \\
\text { aminotransferase malondialdehyde, catalase and } \\
\text { a-smooth muscle actin }\end{array}$ \\
\hline $\begin{array}{l}\text { Mallotus apelta } \\
\text { (Zhao et al., 2002) }\end{array}$ & Root & $\begin{array}{l}\text { Carbon tetra- } \\
\text { chloride }\end{array}$ & Rat & $\begin{array}{l}\text { Meth- } \\
\text { anolic }\end{array}$ & $\begin{array}{l}\text { ALT, AST, MDA, NO and hydroxyproline in the } \\
\text { blood or liver tissues }\end{array}$ \\
\hline
\end{tabular}

cantly reduced as compared to the control. Protein expression of a-smooth muscle was also downregulated, which is a clear indication of the inhibition of hepatic stellate cell activation. Liver malodialdehyde concentration and serum cholesterol level in rat treated with the plant extract were highly reduced when compared with the control group (Park et al., 2000).

\section{Stephania tetrandra}

The pharmacological active compound derived from the Stephania tetrandra is tetrandrine. Tetrandrine acts as an antagonist of the calcium channel which is important for the hepatic stellate cell function and regulation (Hsu et al., 2007). It also plays an important role in the cancer therapy (Chen, 2002; Wang et al., 2004), anti-inflammatory effect (Choi et al., 2000). Various studies on isolated compound tetrandrine from the plant show that it has the potential for anti-fibrotic effect in different types of cell lines. Hepatic fibrosis model was prepared by using scission and bile duct ligation in the rat. After surgery, rat was treated with tetrandrine 10 $\mathrm{mg} / \mathrm{kg}$ daily. It significantly reduces the serum aminotransferases, alkaline phosphatase and liver hydroxyproline concentration in the treated groups when compared with the control group. On cultured rat hepatic stellate cells, tetrandrine has a significant effect on the expression of a-smooth muscles. a-Smooth muscle actin expression was unregulated in the hepatic stellate cell activation. Tetrandrine has the potential to decrease the expression of a-smooth muscle actin (Park et al., 2000a).

\section{Gynostemma pentaphyllum}

The active pharmacological compound extracted from Gynostemma pentaphyllum is gypenoside. It has hepatoprotective properties (Lin et al., 1993) and also has therapeutic potiential in the liver fibrosis. The saponin extract gypenoside of the plant has potential to prevent the acute and chronic liver injury induced by $\mathrm{CCl}_{4}$ for 8 weeks in the rat model. Gypenoside treated rat significantly reduces the concentration of serum aminotransferases when compared to the control and collagen production is also reduced to $33 \%$ (Chen et al., 2000).

\section{Hibiscus sabdariffa}

Hibiscus sabdariffa is one of the famous Chinese rose tea and is also used as folk medicines for the relief of different pathopysiological disorders e.g., liver damage (Tseng et al., 1997), hypertension (Herrera-Arellano et al., 2004; Onyenekwe et al., 1999). It has a strong antioxidant effect (Tsai et al., 2002). Dried flower extract of the plant has the potential for the prevention of liver fibrosis in rat model. Rats were administered $\mathrm{CCl}_{4}$ through intraperitoneal injection for 7 weeks. The flower extract highly reduced the liver injury and fibrosis in a dose-dependent manner. It also significantly reduces the serum aminotransferases and also normalizes the glutathione concentration (Liu et al., 2006b).

\section{Scutellaria baicalensis}

Scutellaria baicalensis is a traditional herb widely used in different countries like Korea, China and Japan. It is 
commonly used in the liver diseases and inflammatory conditions (Huang et al., 2006; Pan et al., 2012). It has a strong anti-oxidant activity and is rich in flavonoids content (Gao et al., 1999; Huang et al., 2006). The methanolic extract of the plant has the therapeutic effect against the liver fibrosis induced by the bile duct ligation and scission or $\mathrm{CCl}_{4}$-induced in the rat model. The fibrotic rat model was assessed by measuring liver enzyme concentration and histopathological observations. The methanol extract of the plant was administered orally $150 \mathrm{mg} / \mathrm{kg}$ for 28 days daily. The level of liver hydroxyproline and malondialdehyde was significantly reduced in treated groups when compared to the control. Masson's trichrome staining and immunostaining for a-smooth muscle actin showed improved liver tissue histology in the treated groups (Nan et al., 2002).

\section{Piper betel}

Piper betel has a significant role in the treatment of different diseases because of an significant amount of anti-oxidants present such as $\beta$-carotene, eugenol, ascorbic acid and hydroxychavicol (Capdevielle-Pardies et al., 1985; Norton, 1998). It has a significant effect in the reversal and protection of liver fibrosis. The leaves of the plant have therapeutic value for detoxication, anti -oxidation and antimutation effects. The rat model of the liver injury was prepared by $\mathrm{CCl}_{4}$ administration thrice a week at a dose of $1 \mathrm{~mL} / \mathrm{kg}$. Liver damage and fibrosis were assessed by the liver enzymes and histological findings. The extract from the leaves played a significant role in the inhibition of increased concentration of serum aminotransferases and total glutathione S-transferase activity (GST). The histological findings showed the protective effect of the liver injury through a decrease in a-smooth muscle actin and inducting the matrix metalloproteinase-2 expression (Young et al., 2007).

\section{Foeniculum vulgare}

The plant parts including leaf, seed and stalk are edible. The plant has anti-microbial, anti-oxidant, anti-inflammatory and also hepatoprotective activities (Choi and Hwang, 2004; Oktay et al., 2003; Özbek et al., 2003). Hepatoprotective effect of the plant was studied using the liver fibrosis model. Liver fibrosis was induced in rat. Essential oil of the plant significantly attenuates the concentration of serum aminotransferases, alkaline phosphatase and bilirubin. It also plays a significant role in the prevention of liver fibrosis when co-administered with $\mathrm{CCl}_{4}$ as revealed through the histopathological findings. So, it has the potential for reversal of liver fibrosis and improves the micro-environment of the liver (Özbek et al., 2004).

\section{Bidens pilosa}

Bidens pilosa is an important and active ingredient of the tea in China. The percentage of usage of this plant in different herbal treatment is comparatively higher than other herbal plants. It is widely used as antimalarial, stomach disorders, hypertension and anti-inflammatory (Alvarez et al., 1999; Andrade-Neto et al., 2004; Dimo et al., 2002; Pereira et al., 1999). The therapeutic potential for the liver fibrosis of the plant was assessed through rat and mouse model of the liver injury. Liver injury was induced by $\mathrm{CCl}_{4}$. Plant extract was administered orally for 10 days at three different doses $(25,50,100$ $\mathrm{mg} / \mathrm{kg}$ ) to $\mathrm{CCl}_{4}$-treated mouse and administration of three different doses of the plant $(30,60,90 \mathrm{mg} / \mathrm{kg})$ for 6 weeks to treated rat. Liver enzymes (aminotransferases, malondialdehyde, SOD, GSH-Px) were increased during liver injury and histopathological examination and nuclear factor- $\mathrm{kB}$ were also assessed for the liver injury and fibrosis. The plant extract significantly reduced all the parameters which were assessed for the liver injury and fibrosis model in mouse and rat. The histopathological findings showed that it attenuates the severity of liver fibrosis which might be linked to its anti-oxidant property (Yuan et al., 2008b).

\section{Han-Dan-Gan-Le}

Han-Dan-Gan-Le is composed of five different medicinal herbs (Ginkgo biloba, Radix paoniae, Salvia miltorrhiza, Stephaniat tetrandra and Astragalus membranaceus) from the China. It is claimed to be helpful in the treatment of liver fibrosis. This property was examined through chemical induction of liver fibrosis in rat model. $\mathrm{CCl}_{4}$ was administered two times per week $1.2 \mathrm{~mL} / \mathrm{kg}$, after the first dose of $5 \mathrm{~mL} / \mathrm{kg}$, subcutaneously. After the last dose of $\mathrm{CCl}_{4}$, the mixture was administered $0.5-1 / \mathrm{kg}$ through intragastric route for 6 weeks daily. The treatment for 6 weeks had great influence on the reversal of liver fibrosis. Immunohistochemical analysis revealed that the hepatic collagen accumulation was reduced by treatment. Urinary analysis showed that Han-Dan-GanLe stimulated the collagenolytic signaling in the liver as $30-50 \%$ excretion of hydroxyproline was present in urine sample when compared to the control (Li et al., 2003).

\section{Lygodium flexuosum}

Lygodium flexuosum is most commonly found in India. It has potential in the treatment of liver diseases. The protective and treatment effect of the plant was assessed through liver injury and fibrosis in rat model. Chronic liver fibrosis model was induced by $\mathrm{CCl}_{4} 150$ $\mu \mathrm{L} / 100 \mathrm{~g}$ twice a week for 10 weeks. After 10 weeks, the plant extract was given orally for 2 weeks at a dose of $200 \mathrm{mg} / \mathrm{kg}$. In the preventive group, the daily dose was administered with $\mathrm{CCl}_{4}$ for 10 weeks. Both groups showed reduced mRNA levels of proinflammatory cytokines, signaling molecules, growth factors which have a potential role in the liver fibrosis. Treatment with the plant extract has the potential for downregulation of tumor necrosis factor- $\alpha$, transforming growth factor, interleukin-1 $\beta$, procollagen-I, pro- 
collagen-III and tissue inhibitor of metalloproteinase-1 when compared with the control group. The upregulation of matrix metalloproteinase-13 in the treated and protective groups were the indication of improvement of liver fibrosis (Wills and Asha, 2007).

\section{Paeonia lactiflora and Radix astragali}

Both plants have hepatoprotective effect. The mixtures of these plants are used in the treatment of liver disorders because they have synergistic effect to treat liver fibrosis. To explore the possible mechanism, liver fibrosis rat model was induced by the injection of $50 \%$ $\mathrm{CCl}_{4}$ twice a week for 8 weeks. Preventive groups were also receiving the mixture at three different doses 40 , $80,160 \mathrm{mg} / \mathrm{kg}$ through intragastric route. Liver damage was assessed by liver enzymes concentration, hyaluronic acid, laminin, procollagen type III concentration and contents of hydroxyproline. Treated groups have significantly reduced level of the above said parameters when compared to the control. The mixture also restored the normal level of SOD and GSH-Px and also attenuated the formation of malondialdehyde. In primary cell studies, hepatic stellate cells were cultured which showed that the mixture significantly reduced the thymidine incorporation in hepatic stellate cells stimulated with the platelet derived homodimer subunit of growth factoe- $\beta$ and also reduced incorporation of proline. The possible mechanism of reversal of liver fibrosis might be linked with the scavenge of free radicals, proliferation in hepatic stellate cells and inhibition of collagen synthesis (Sun et al., 2007).

\section{Zizyphusspina-christi}

Zizyphusspina-christi is mainly used for the hepatoprotective, anti-inflammatory, antiseptic, antimicrobial and also urinary tract disorders (Amin and MahmoudGhoneim, 2009b; Tanira et al., 1988). It is enriched with sterols, tannins, butulinic acid and flavonoids (Amin and Mahmoud-Ghoneim, 2009b; Pawlowska et al., 2009). The potential of the plant in liver fibrosis treatment was assessed by $\mathrm{CCl}_{4}$-induced liver rat model. The extract was administered daily in the treated group at 3 different doses $0.125,0.250$ and $0.350 \mathrm{~g} / \mathrm{kg}$ for 8 weeks. Treated group showed significantly reduced concentration of the serum aminotransferases and also resorted the normal concentration of malondialdehyde and also maintain the normal endogenous concentration of anti-oxidants. Histopathological examination revealed that it also down-regulates the expression of asmooth muscle actin and the deposition of collagen in the treated group (Amin and Mahmoud-Ghoneim, 2009b).

\section{Green tea}

Green tea extract has a beneficial effect on the vital organ of the body such as liver and kidney which are apparent within the 30 days. It also improves the function of the liver in disease condition and resolution of liver fibrosis. It was investigated in the liver fibrosis model induced by $\mathrm{CCl}_{4}$ only, ethanol only and combination of these two in the rat. Scanning electron microscopy was used to investigate the prevention of liver fibrosis. This technique was used to study type, thickness and distribution of fibers in all the groups. The treatment with green tea extract improves the architecture of the liver and also improves the body weight. The liver autopsy showed that the treated rat has normal shape and color liver when compared to the liver fibrosis model group and normal rat group. The green tea extract improves the liver function through collagen fibers resolution, reduction in the lipid peroxidation product (Safer et al., 2015).

\section{Ocimum gratissimum}

Ocimum gratissimum is widely used as herbal medicine. It is found in the tropical and warm temperature areas. This plant is enriched with anti-oxidant compounds (Prakash et al., 2011). It has important pharmacological effects including the antibacterial (Nakamura et al., 1999), hypoglycemic activity (Aguiyi et al., 2000) and also improves the liver function. The polyphenol extract of the plant was used to investigate the anti-fibrotic activity of the plant. Liver fibrosis was induced in male Wistar rats through the administration of $\mathrm{CCl}_{4}$. the extract of the plant was administered at different doses according to body weight for 8 weeks. It significantly reduced the toxic effects of $\mathrm{CCl}_{4}$ such as liver weight, serum aminotransferases, malondialdehyde, catalase when compared with the control group. These effects might be due to the anti-oxidant property of the plant and also high polyphenol concentrations were important for high anti-fibrotic activity (Chen et al., 2015).

\section{Mallotus apelt}

Mallotus apelt is found in south of China. It is commonly used in the treatment of chronic hepatitis (Cheng et al., 1998) and contains special type of alkaloids (Cheng et al., 1998) and show significant role in the liver diseases ( $\mathrm{Xu}$ et al., 2008). The root of the plant was studied for its anti-fibrotic and anti-oxidant effect in the liver fibrotic model. Liver fibrosis was induced in rats with the administration of $40 \% \mathrm{CCl}_{4}$ in peanut oil. Blood concentration for the liver enzymes (serum aminotransferases, malondialdehyde, hydroxyproline) were analyzed. These were significantly reduced in the treated group when compared to the control group. It also improved the overall performance of liver which might be due to anti-oxidant components present in the plant (Zhao et al., 2002).

\section{Conclusion}

The goal of the liver fibrosis studies on natural plants should not be restricted to all types of severe liver 
diseases. Effective formulations have to be developed using native medicinal plants, with proper pharmacological experiments and clinical trials. The manufacturing of plant products should be governed by the standards of safety and efficacy. The plants described in this review have the potential for reversal of liver fibrosis.

\section{Conflict of Interest}

All authors have completed the ICMJE uniform disclosure form and declare no support from any organization for the submitted work.

\section{References}

Abdel-Aziz G, Lebeau G, Rescan P, Clement B, Rissel M, Deugnier Y, Campion J, Guillouzo A. Reversibility of hepatic fibrosis in experimentally-induced cholestasis in rat. Am J Pathol. 1990; 137: 1333.

Aguiyi JC, Obi CI, Gang SS, Igweh AC. Hypoglycaemic activity of Ocimum gratissimum in rats. Fitoterapia 2000; 71: 44446.

Alvarez A, Pomar F, Sevilla M, Montero M. Gastric antisecretory and antiulcer activities of an ethanolic extract of Bidens pilosa L var radiata Schult Bip. J Ethnopharmacol. 1999; 67: 333-40.

Amin A, Mahmoud-Ghoneim D. Zizyphus spina-christi protects against carbon tetrachloride-induced liver fibrosis in rats. Food Chem Toxicol. 2009; 47: 2111-19.

Andrade-Neto VF, Brandão MG, Oliveira FQ, Casali VW, Njaine B, Zalis MG, Oliveira LA, Krettli AU. Antimalarial activity of Bidens pilosa L. (Asteraceae) ethanol extracts from wild plants collected in various localities or plants cultivated in humus soil. Phytother Res. 2004; 18: 634-39.

Arthur MJ. Reversibility of liver fibrosis and cirrhosis following treatment for hepatitis C. Gastroenterology 2002; 122: 1525-28.

Bataller R, Brenner DA. Liver fibrosis. J Clin Invest. 2005; 115: 209-18.

Benyon R, Iredale J. Is liver fibrosis reversible? Gut 2000; 46: $443-46$.

Can A, Akev N, Ozsoy N, Bolkent S, Arda BP, Yanardag R, Okyar A. Effect of Aloe vera leaf gel and pulp extracts on the liver in type-II diabetic rat models. Biol Pharm Bull. 2004; 27: 694-98.

Capdevielle-Pardies P, David J, Miquel J, Le Bras M. Quid of betel. Med Trop. 1985; 45: 299-307.

Chandan B, Saxena A, Shukla S, Sharma N, Gupta D, Suri K, Suri J, Bhadauria M, Singh B. Hepatoprotective potential of Aloe barbadensis Mill. Against carbon tetrachloride induced hepatotoxicity. J Ethnopharmacol. 2007; 111: 560-66.

Chen JC, Tsai CC, Chen LD, Chen HH, Wang WC. Therapeutic effect of gypenoside on chronic liver injury and fibrosis induced by $\mathrm{CCl}_{4}$ in rats. Am J Chinese Med. 2000; 28:175-85.

Chen YH, Chiu YW, Shyu JC, Tsai CC, Lee HH, Hung CC, Hwang JM, Liu JY, Wang WH. Protective effects of Ocimum gratissimum polyphenol extract on carbon tetrachlorideinduced liver fibrosis in rats. Chinese J Physiol. 2015; 58: 5563.

Chen YJ. Potential role of tetrandrine in cancer therapy. Acta Pharmacol Sin. 2002; 23: 1102-06.

Chen YH, Chiu YW, Shyu JC, Tsai CC, Lee HH, Hung CC, Hwang JM, Liu JY, Wang WH. Protective effects of Ocimum gratissimum polyphenol extract on carbon tetrachlorideinduced liver fibrosis in rats. Chinese J Physiol. 2015; 58: 5563.

Cheng XF, Meng ZM, Chen ZL. A pyridine-type alkaloid from Mallotus apelta. Phytochemistry 1998; 49: 2193-94.

Cheng X, Di L, Wu Y, Zhao Q, Du G, Liu Y. Studies on the hypoglycemic effect of Rhodiola sachalinensis A. Bor. polysaccharides. Zhongguo Zhong yao za zhi Zhongguo zhongyao zazhi= China J Chinese Materia Medica. 1993; 18: 557-59.

Choe KI, Kwon JH, Park KH, Oh MH, Kim MH, Kim HH, Cho SH, Chung EK, Ha SY, Lee MW. The anti-oxidant and antiinflammatory effects of phenolic compounds isolated from the root of Rhodiola sachalinensis A. BOR. Molecules 2012; 17: 11484-94.

Choi EM, Hwang JK. Anti-inflammatory, analgesic and antioxidant activities of the fruit of Foeniculum vulgare. Fitoterapia 2004; 75: 557-65.

Choi HS, Kim HS, Min KR, Kim Y, Lim HK, Chang YK, Chung MW. Anti-inflammatory effects of fangchinoline and tetrandrine. J Ethnopharmacol. 2000; 69: 173-79.

Constandinou C, Henderson N, Iredale JP. Modeling liver fibrosis in rodents. In: Fibrosis Research. Springer, 2005, pp 237-50.

Delire B, Stärkel P, Leclercq I. Animal models for fibrotic liver diseases: What we have, what we need, and what is under development. J Clin Translational Hepatol. 2015; 3: 53.

Dimo T, Rakotonirina SV, Tan PV, Azay J, Dongo E, Cros G. Leaf methanol extract of Bidens pilosa prevents and attenuates the hypertension induced by high-fructose diet in Wistar rats. J Ethnopharmacol. 2002; 83: 183-91.

Friedman SL, Bansal MB. Reversal of hepatic fibrosis: Fact or fantasy? Hepatology 2006; 43: S82-S8.

Gao Z, Huang K, Yang X, Xu H. Free radical scavenging and anti-oxidant activities of flavonoids extracted from the radix of Scutellaria baicalensis Georgi. Biochimica et Biophysica Acta (BBA). 1999; 1472: 643-50.

Gonzalez S, Fiel M, Sauk J, Canchis P, Liu RC, Chiriboga L, Yee $\mathrm{H}$, Jacobson I, Talal A. Inverse association between hepatic stellate cell apoptosis and fibrosis in chronic hepatitis C virus infection. J Viral Hepat. 2009; 16: 141-48.

Hammel P, Couvelard A, O'Toole D, Ratouis A, Sauvanet A, Fléjou JF, Degott C, Belghiti J, Bernades P, Valla D. Regression of liver fibrosis after biliary drainage in patients with chronic pancreatitis and stenosis of the common bile duct. $\mathrm{N}$ 
Engl J Med. 2001; 344: 418-23.

Herrera-Arellano A, Flores-Romero S, Chavez-Soto M, Tortoriello J. Effectiveness and tolerability of a standardized extract from Hibiscus sabdariffa in patients with mild to moderate hypertension: A controlled and randomized clinical trial. Phytomedicine 2004; 11: 375-82.

Hsu YC, Chiu YT, Cheng CC, Wu CF, Lin YL, Huang YT. Antifibrotic effects of tetrandrine on hepatic stellate cells and rats with liver fibrosis. J Gastroenterol Hepatol. 2007; 22: 99-111.

Huang WH, Lee AR, Yang CH. Anti-oxidative and anti-inflammatory activities of polyhydroxyflavonoids of Scutellaria baicalensis GEORGI. Biosci Biotechnol Biochem. 2006; 70: 2371-80.

Ji XY, Tan B, Zhu YZ. Salvia miltiorrhiza and ischemic diseases. Acta Pharmacol Sin. 2000; 21: 1089-94.

Kim MH, Kim SI, Seo DW, Ryu JC, Choi HY. Anti-oxidant activity of Salvia miltiorrhiza Bunge, a novel foodstuff. Mol Cell Toxicol. 2010; 6: 65-72.

Kim SH, Cheon HJ, Yun N, Oh ST, Shin E, Shim KS, Lee SM. Protective effect of a mixture of Aloe vera and Silybum marianum against carbon tetrachloride-induced acute hepatotoxicity and liver fibrosis. J Pharmacol Sci. 2009; 109: 119.

Kim SH, Cheon HJ, Yun N, Oh ST, Shin E, Shim KS, Lee SM. Protective effect of a mixture of Aloe vera and Silybum marianum against carbon tetrachloride-induced acute hepatotoxicity and liver fibrosis. J Pharmacol Sci. 2009; 109: 11927.

Kisseleva T, Cong M, Paik Y, Scholten D, Jiang C, Benner C, Iwaisako K, Moore-Morris T, Scott B, Tsukamoto H. Myofibroblasts revert to an inactive phenotype during regression of liver fibrosis. Proc Natl Acad Sci USA. 2012; 109: 9448-53.

Krizhanovsky V, Yon M, Dickins RA, Hearn S, Simon J, Miething C, Yee H, Zender L, Lowe SW. Senescence of activated stellate cells limits liver fibrosis. Cell 2008; 134: 65767.

Lee MW, Lee YA, Park HM, Toh SH, Lee EJ, Jang HD, Kim YH. Anti-oxidative phenolic compounds from the roots of Rhodiola sachalinensis A. Bor. Arch Pharm Res. 2000; 23: 455.

Lee TY, Wang GJ, Chiu JH, Lin HC. Long-term administration of Salvia miltiorrhiza ameliorates carbon tetrachlorideinduced hepatic fibrosis in rats. J Pharm Pharmacol. 2003; 55: 1561-68.

Li C, Luo J, Li L, Cheng M, Huang N, Liu J, Waalkes MP. The collagenolytic effects of the traditional Chinese medicine preparation, Han-Dan-Gan-Le, contribute to reversal of chemical-induced liver fibrosis in rats. Life Sci. 2003; 72: 1563 -71 .

Lim BO, Seong NS, Choue RW, Dal KIM J, Lee HY, Kim SY, Yu BP, Jeon TI, PARK DK. Supplementation on hepatic cholesterol and oxidative status in aged rats. J Nutr Sci Vitaminol. 2003; 49: 292-96.

Lin JM, Lin CC, Chiu HF, Yang JJ, Lee SG. Evaluation of the anti-inflammatory and liver-protective effects of Anoectochilus formosanus, Ganoderma lucidum and Gynostemma pentaphyllum in rats. Am J Chinese Med. 1993; 21: 59-69.
Liu JY, Chen CC, Wang WH, Hsu JD, Yang MY, Wang CJ. The protective effects of Hibiscus sabdariffa extract on $\mathrm{CCl}_{4-}$ induced liver fibrosis in rats. Food Chem Toxicol. 2006; 44: $336-43$.

Liu Y, Meyer C, Xu C, Weng H, Hellerbrand C, ten Dijke P, Dooley S. Animal models of chronic liver diseases. Am J Physiol Gastrointest Liver Physiol. 2013; 304: G449-68.

Mallet V, Gilgenkrantz H, Serpaggi J, Verkarre V, ValletPichard A, Fontaine H, Pol S. Brief communication: The relationship of regression of cirrhosis to outcome in chronic hepatitis C. Annals Int Med. 2008; 149: 399-403.

Nakamura CV, Ueda-Nakamura T, Bando E, Melo AFN, Cortez DAG, Dias Filho BP. Antibacterial activity of Ocimum gratissimum L. essential oil. Memórias do Instituto Oswaldo Cruz. 1999; 94: 675-78.

Nan JX, Jiang YZ, Park EJ, Ko G, Kim YC, Sohn DH. Protective effect of Rhodiola sachalinensis extract on carbon tetrachlorideinduced liver injury in rats. J Ethnopharmacol. 2003; 84: 14348 .

Nan JX, Jiang YZ, Park EJ, Ko G, Kim YC, Sohn DH. Protective effect of Rhodiola sachalinensis extract on carbon tetrachlorideinduced liver injury in rats. J Ethnopharmacol. 2003; 84: 14348 .

Nan JX, Park EJ, Kang HC, Park PH, Kim JY, Sohn DH. Antifibrotic effects of a hot-water extract from Salvia miltiorrhiza roots on liver fibrosis induced by biliary obstruction in rats. J Pharm Pharmacol. 2001; 53: 197-204.

Nan JX, Park EJ, Kang HC, Park PH, Kim JY, Sohn DH. Antifibrotic effects of a hot-water extract from Salvia miltiorrhiza roots on liver fibrosis induced by biliary obstruction in rats. J Pharm Pharmacol. 2001; 53: 197-204.

Nan JX, Park EJ, Kim YC, Ko G, Sohn DH. Scutellaria baicalensis inhibits liver fibrosis induced by bile duct ligation or carbon tetrachloride in rats. J Pharm Pharmacol. 2002; 54: 555-63.

Norton SA. Betel: Consumption and consequences. J Am Academ Dermatol. 1998; 38: 81-88.

Oktay M, Gülçin İ, Küfrevioğlu Öİ. Determination of in vitro anti-oxidant activity of fennel (Foeniculum vulgare) seed extracts. LWT-Food Sci Technol. 2003; 36: 263-71.

Onyenekwe P, Ajani E, Ameh D, Gamaniel K. Antihypertensive effect of roselle (Hibiscus sabdariffa) calyx infusion in spontaneously hypertensive rats and a comparison of its toxicity with that in Wistar rats. Cell Biochem Function. 1999; 17: 199-206.

Özbek H, Ugras S, Bayram I, Uygan I, Erdogan E, Öztürk A, Huyut Z. Hepatoprotective effect of Foeniculum vulgare essential oil: A carbon-tetrachloride induced liver fibrosis model in rats. Scand J Lab Anim Sci. 2004; 31: 9-17.

Özbek H, Uğraş S, Dülger H, Bayram I, Tuncer I, Öztürk G, Öztürk A. Hepatoprotective effect of Foeniculum vulgare essential oil. Fitoterapia 2003; 74: 317-19.

Paik YH, Brenner DA. NADPH oxidase mediated oxidative stress in hepatic fibrogenesis. Korean J Hepatol. 2011; 17: 251 $-57$.

Paik YH, Kim J, Aoyama T, De Minicis S, Bataller R, Brenner 
DA. Role of NADPH oxidases in liver fibrosis. Antioxid Redox Signal. 2014; 20: 2854-72.

Paik YH, Kim J, Aoyama T, De Minicis S, Bataller R, Brenner DA. Role of NADPH oxidases in liver fibrosis. Anti-oxidants and redox signaling. 2014; 20: 2854-72.

Pan TL, Wang PW, Leu YL, Wu TH, Wu TS. Inhibitory effects of Scutellaria baicalensis extract on hepatic stellate cells through inducing G 2/M cell cycle arrest and activating ERK -dependent apoptosis via Bax and caspase pathway. J Ethnopharmacol. 2012; 139: 829-37.

Park EJ, Nan JX, Kim JY, Kang HC, Choi JH, Lee SJ, Lee BH, Kim SJ, Lee JH, Kim YC. The ethanol-soluble part of a hotwater extract from Artemisia iwayomogi inhibits liver fibrosis induced by carbon tetrachloride in rats. J Pharm Pharmacol. 2000; 52: 875-81.

Park PH, Nan JX, Park EJ, Kang HC, Kim JY, Ko G, Sohn DH. Effect of tetrandrine on experimental hepatic fibrosis induced by bile duct ligation and scission in rats. Basic Clin Pharmacol Toxicol. 2000; 87: 261-68.

Park PH, Nan JX, Park EJ, Kang HC, Kim JY, Ko G, Sohn DH. Effect of tetrandrine on experimental hepatic fibrosis induced by bile duct ligation and scission in rats. Pharmacol Toxicol. 2000; 87: 261-68.

Pawlowska AM, Camangi F, Bader A, Braca A. Flavonoids of Zizyphus jujuba L. and Zizyphus spina-christi (L.) Willd (Rhamnaceae) fruits. Food Chem. 2009; 112: 858-62.

Pellicoro A, Ramachandran P, Iredale JP, Fallowfield JA. Liver fibrosis and repair: Immune regulation of wound healing in a solid organ. Nat Rev Immunol. 2014; 14: 181-94.

Pereira RL, Ibrahim T, Lucchetti L, da Silva AJR, de Moraes VLG. Immunosuppressive and anti-inflammatory effects of methanolic extract and the polyacetylene isolated from Bidens pilosa L. Immunopharmacology 1999; 43: 31-37.

Post-White J, Ladas EJ, Kelly KM. Advances in the use of milk thistle (Silybum marianum). Integr Cancer Ther. 2007; 6: 10409.

Prakash B, Shukla R, Singh P, Mishra PK, Dubey NK, Kharwar RN. Efficacy of chemically characterized Ocimum gratissimum L. essential oil as an anti-oxidant and a safe plant based antimicrobial against fungal and aflatoxin B1 contamination of spices. Food Res Intern. 2011; 44: 385-90.

Qi X. Protective mechanism of Salvia miltiorrhiza and Paeonia lactiflora for experimental liver damage. Zhong xi yi jie he za zhi= Chinese J Modern Develop Tradit Med. 1991; 11: 102-04.

Safer AM, Afzal M, Hanafy N, Mousa S. Green tea extract therapy diminishes hepatic fibrosis mediated by dual exposure to carbon tetrachloride and ethanol: A histopathological study. Exp Ther Med. 2015; 9: 787-94.

Starkel P, Leclercq I. Animal models for the study of hepatic fibrosis. Best Prac Res Clin Gastroenterol. 2011; 25: 319-33.
Sun WY, Wei W, Wu L, Gui SY, Wang H. Effects and mechanisms of extract from Paeonia lactiflora and Astragalus membranaceus on liver fibrosis induced by carbon tetrachloride in rats. J Ethnopharmacol. 2007; 112: 514-23.

Tanira MO, Ageel A, Tariq M, Mohsin A, Shah A. Evaluation of some pharmacological, microbiological and physical properties of Zizyphus spina-christi. Int J Crude Drug Res. 1988; 26: 56-60.

Tsai PJ, McIntosh J, Pearce P, Camden B, Jordan BR. Anthocyanin and anti-oxidant capacity in Roselle (Hibiscus sabdariffa L.) extract. Food Res Int. 2002; 35: 351-56.

Tseng TH, Kao ES, Chu CY, Chou FP, Wu HWL, Wang CJ. Protective effects of dried flower extracts of Hibiscus sabdariffa L. against oxidative stress in rat primary hepatocytes. Food Chem Toxicol. 1997; 35: 1159-64.

Uehara T, Pogribny IP, Rusyn I. The DEN and CCl4-induced mouse model of fibrosis and inflammation-associated hepatocellular carcinoma. Curr Protoc Pharmacol. 2014: 14.30. 114.30. 10.

Vaknin Y, Hadas R, Schafferman D, Murkhovsky L, Bashan N. The potential of milk thistle (Silybum marianum L.), an Israeli native, as a source of edible sprouts rich in antioxidants. Int J Food Sci Nutr. 2008; 59: 339-46.

Wang G, Lemos JR, Iadecola C. Herbal alkaloid tetrandrine: From an ion channel blocker to inhibitor of tumor proliferation. Trends Pharmacol Sci. 2004; 25: 120-23.

WHO. Research guidelines for evaluating the safety and efficacy of herbal medicines 1993. Available from: http:// apps.who.int/medicinedocs/en/d/Jh2946e/.

Wills P, Asha V. Protective mechanism of Lygodium flexuosum extract in treating and preventing carbon tetrachloride induced hepatic fibrosis in rats. Chem Biol Interact. 2007; 165: 76-85.

Wu J, Norton PA. Animal models of liver fibrosis. Scand J Gastroenterol. 1996; 31: 1137-43.

Xu JF, Feng ZM, Liu J, Zhang PC. New hepatoprotective coumarinolignoids from Mallotus apelta. Chem Biodivers. 2008; 5: 591-97.

Young SC, Wang CJ, Lin JJ, Peng PL, Hsu JL, Chou FP. Protection effect of Piper betel leaf extract against carbon tetrachloride-induced liver fibrosis in rats. Arch Toxicol. 2007; 81: 45-55.

Yuan LP, Chen FH, Ling L, Dou PF, Bo H, Zhong MM, Xia LJ. Protective effects of total flavonoids of Bidens pilosa L. (TFB) on animal liver injury and liver fibrosis. J Ethnopharmacol. 2008; 116: 539-46.

Zhao J, Lu Z, Wang X, Zhang X. The study on the antioxidation effect of root of Mallotus apelta in the rat model of liver fibrosis. Zhong yao cai $=$ Zhongyaocai $=\mathrm{J}$ Chinese Med Materials. 2002; 25: 185-87. 